\title{
An experimental study on the effect of systemic functional linguistics applied through a genre-pedagogy approach to teaching writing
}

\author{
May Olaug Horverak \\ Department of Nordic and Media Studies, University of Agder \\ may.o.horverak@uia.no
}

\begin{abstract}
In the tradition of teaching English as a second language, there has been an increased interest in how functional language descriptions and understandings of genres may be used as resources for making meaning. The present study investigates what impact writing instruction that draws upon systemic functional linguistics (SFL) applied through a genre-pedagogy approach has on students' ability to write argumentative essays. This includes explicit grammar instruction inspired by SFL, as well as instruction on text structure. The study uses a mixed-methods approach, with a quasiexperiment followed up by quantitative and qualitative analyses of the collected material. Statistical analyses indicate a significant positive effect on writing performance in the intervention groups, regardless of gender, first language and previous level of writing. As the study lacks control groups, the quantitative analysis was complemented with examples from student texts to illustrate the improvement revealed in the statistical analysis. The findings suggest that SFL applied through a genre-pedagogy approach to teaching writing may help students to improve their writing skills.
\end{abstract}

Keywords: writing instruction; genre-pedagogy; systemic functional linguistics; explicit grammar teaching.

\section{Introduction}

Learning to write in a second language (L2) is more demanding than learning to write in the first language (L1). In Silva's research review of L2 writing (1993), his findings suggested that L2 writers have more difficulty with organizing material when writing than do L1 writers. He pointed out that there was "a need to include more work on planning - to generate ideas, text struc- 
ture, and language" (Silva 1993: 671) in the teaching of L2 writers. Learning to write argumentative texts in school is a challenge in general (Andrews 1995; Beard 2000; Berge et al. 2005; Freedman and Pringle, 1988), so this is probably also a challenge in L2 contexts. The need for writing instruction that focuses on planning, text structure and language is addressed in various genre-based pedagogies that have been developed and transferred to L2 contexts, and is also addressed in this article, with a specific focus on how to teach argumentative writing.

Common to the genre-based pedagogies that have developed during the last decades is the focus on context (Freedman and Medway 1994). This means that they focus on teaching how to adjust writing to purpose and situation. In a review on genre as tool for developing instruction in L1 and L2 contexts, three different traditions are outlined: (a) English for Specific Purposes, or ESP; (b) North American New Rhetoric studies; and (c) Australian systemic functional linguistics, or Australian genre-pedagogy (Hyon 1996). Hyon found that ESP approaches and the Australian genre-pedagogy focused on linguistic features of written texts and guidelines for presenting these in the classroom, whereas the North American New Rhetoric approaches focused more on the institutional contexts and functions of genres. In spite of differences, all genre-based pedagogies focus on adjusting writing to purpose and situation, which is a central concern when learning languages (Council of Europe 2003).

Originally, the Australian genre-pedagogy developed in primary school as a strategy to support all pupils with regard to mastering genres required of them in school context regardless of their background (Cope et al. 2012). This pedagogy was influenced by Halliday's systemic functional linguistics (SFL), a theory that outlines systems of language choices from which the language user may choose in various contexts (Halliday and Matthiessen 2014). In genre-pedagogy, there is a focus on context and on revealing what is typical of different types of texts in terms of language and structure. In the Australian tradition, genres are seen as constructed in stages, or in a kind of set pattern and knowing these is an important step in learning how to produce texts of various genres (J.R. Martin 2012; J.R. Martin and Rothery 2012). This has led to the development of a teaching-learning cycle for the teaching of writing with three main stages: (a) modelling or deconstruction of text; (b) joint construction of text, meaning that the teacher writes a text together with the whole group of students; and (c) independent construction of text includ- 
ing consultations with the teacher and peers (Cope and Kalantzis 2012; Rose 2009).

Genre-pedagogy developed through a series of action research projects (Rose 2009), first the LERN Project (Literacy and Education Research Network) which also joined the Language and Social Power Project, second the Write it Right project, and third, the Reading to Learn project. The conclusion of the report from the LERN Project was that the programme had generated a very positive response from the participating teachers, and the approach was found particularly useful in the teaching of how to write factual texts in primary school (Walsh et al. 1990). Another recent longitudinal study with a similar type of approach revealed that growth in writing was related to use of functional meta-language, modelling example texts and feedback on writing (Humphrey and Macnaught 2015). This study was carried out in an Australian upper secondary school with most students from other language backgrounds than English

The second and third phase of the developments in the Australian genrepedagogy moved the focus beyond developing a strategy for the teaching of writing. The second phase, Write it Right, focused on mapping what genres are necessary to include in curricula to meet the literary demands of society (J.R. Martin and Rose 2008). The third phase, Reading to Learn, integrated an approach for detailed reading with the writing instruction practice that had developed in the genre-pedagogy tradition. An extensive action research study comprising 17 schools in an Australian region concluded that this type of approach significantly improved educational outcomes (Koop and Rose 2008). The Reading to Learn approach has also shown a positive outcome in research carried out in higher education (Rose et al. 2008).

In the tradition of teaching English as a second language, there has been an increased interest in how functional language descriptions may be used as a resource for making meaning (Byrnes 2013; Hyland 2007; Johns 2011; Schleppegrell 2013). Much research has been carried out on how genres are learnt by more advanced L2 learners in college or university in English for Specific Purposes contexts, with a focus on professional settings (Angelova and Riazantseva 1999; Bhatia 1993; Gimenez 2008). These studies generally claim that there is a need of support to meet writing expectations in different genres in working life. Australian genre-pedagogy scholars, on the other hand, have focused on primary and secondary school genres (Callaghan et al. 2012; Hammond 1987; Joyce 1992; J.R. Martin 1989, 2012), as pointed out 
by Hyon (1996). Even though the Australian genre-pedagogy has a focus on how to master different genres that are relevant in working life, most of the research has been related to developing curricula and teaching strategies for primary and secondary schools.

The focus of the current study is on teaching argumentative writing in Norwegian upper secondary school. There is a need to investigate this, as argumentative writing seems to be a dominant genre at this level (Horverak 2015, forthcoming), and the majority of students do not feel very confident of their competence to write argumentative texts in English (Horverak, forthcoming). The study referred to here was carried out in 15 upper secondary schools across Norway in first-year general studies classes in the second semester, meaning a few months before a possible final exam. How English writing is taught in lower secondary schools in Norway has not yet been investigated, so it is difficult to know how students are prepared concerning writing before starting in upper secondary school. However, an interviewstudy following up the current study revealed that the students who participated had neither learnt about argumentative writing in English previously, nor about how to adjust language to a formal context (Horverak 2016). However, they reported that this genre was somewhat familiar from Norwegian teaching in lower secondary school, and compared the English "essay" with the Norwegian genre "artikkel", or "article". This genre has the same type of structure as the English "essay"; an introduction with a question for discussion or a thesis statement, main paragraphs with topic sentences introducing arguments and a conclusion. Whether all students have been trained in writing these types of texts in Norwegian in lower secondary school is difficult to know, as there is no specific guideline as to how writing should be taught.

The research question of this study is as follows: What effects does applying systemic functional linguistics through a genre-pedagogy approach to teaching writing have on students' writing skills? To answer this question, a quasi-experiment with a teaching intervention was carried out with 4 classes of first-year students in the general studies branch of Norwegian upper secondary school at the beginning of the first semester. The teaching intervention in this study was influenced by the teaching-learning cycle as presented by Feez (1999), and elaborated on in Hyland's book Genre and second language writing (2004), including the five stages: (1) developing the context; (2) modelling and deconstructing the text; (3) joint construction of the text; (4) independent construction of the text, including support through feedback; and (5) comparing with other texts. The teaching included a focus on how to construct 
argumentative texts in the form of five-paragraph essays, and on adjusting structure and language to a formal context. The choice of grammatical elements to include in the intervention was based on the systems of language presented in SFL. The findings of the study may provide insight into how genre-pedagogy and a linguistic theory such as SFL may be useful for English writing instruction in a Norwegian context, as well as other L2 contexts.

\subsection{English - a second or a foreign language in a Norwegian context?}

English has quite a special status in Norway, as it is unclear whether it should be regarded a second language (L2), or as a foreign language. In the educational system, English has recently changed status from a foreign to a second language (Norwegian Directorate for Education and Training 2006), and the English competence in Norway is generally high (Education First 2012). However, when compared to countries where English is an official language, it is clear that it is not a second language either (Graddol 2006: 84). Instead, it could be said to have an in-between status as neither a foreign nor a second language (Graddol 1997; Rindal 2012: 23; Rindal and Piercy 2013). In the context of upper secondary school, English teaching differs from foreign language teaching as it is not really focused on teaching the language, instead it tends to focus on teaching different social and cultural issues in Englishspeaking countries, as well as on reading literary texts (Norwegian Directorate for Education and Training 2013a).

\subsection{English curriculum and exams in Norwegian upper secondary school}

In Norway, English teaching starts from year 1 in school, and is obligatory for 11 or 12 years throughout the first year of general studies or the second year of vocational studies in upper secondary school. Whereas students who choose general studies have 5 class hours per week the first year, students who choose vocational studies have 3 class hours in year 1 and 2 in year 2 . Hence, English is obligatory for a longer period for these students. The students may get a written or an oral exam after the final obligatory year of English. The exam is the same for general and vocational studies. 
The Knowledge Promotion curriculum reform of 2006 (Norwegian Directorate for Education and Training), and the following 2013 revision (Norwegian Directorate for Education and Training 2013a), introduced a strong focus on what was called basic skills, one of which is writing. This was in line with recommendations developed by the European Parliament and the Council of the European Union (2006). In the English subject curriculum for Norwegian schools, writing competence is specified as "being able to express ideas and opinions in an understandable and purposeful manner [...] planning, formulating and working with texts that communicate and that are well structured and coherent" (Norwegian Directorate for Education and Training 2013a). The students are also required to "use content from different sources in an independent, critical and verifiable manner" (Norwegian Directorate for Education and Training 2013a). The teaching intervention and the choice of measuring instruments in the current study is based on this type of context, in which the students are to be prepared for an exam where their ability to write a coherent argumentative text with references to sources may be tested.

\section{Methodology}

The aim of the present study is to investigate the effects of applying SFL through a genre-pedagogy approach to teaching writing. The design of the study was quasi-experimental without a control group (Shadish et al. 2002: 106). As the study took place in a natural environment, it could also be defined as a field experiment (Langdridge and Hagger-Johnson 2013). In the following, the research design will be presented, as well as the teaching intervention, the research tools, the sample and how the analysis will be performed. Finally, there are some reflections about internal and external validity. The project has been approved by the Data Protection Official for Research (NSD).

\subsection{Research design and measuring instruments - intervention study with pre- and post- tests}

The teaching intervention in this study lasted for four weeks, and started at the very beginning of the first semester. Teaching material was developed in the 
form of PowerPoints, and these included instruction on how to construct argumentative texts as five-paragraph essays. The teaching material was based on Feez's (1999) teaching-learning cycle as presented in Hyland's (2004) Genre and Second Language Writing, except for stage 3, where "joint construction" was changed to "writing practice and grammar instruction" (see Table 1). It also included some grammatical issues that are identified as relevant in SFL to adjust writing to context. More precisely, what was included was explicit grammar instruction on (1) cohesive links such as connectors and pronouns; (2) modality; and (3) formality level of language. The teachers were instructed on how to implement the teaching material in their groups.

Table 1. The teaching intervention.

\begin{tabular}{|c|c|c|}
\hline Stage & Teaching-learning cycle & Content \\
\hline First & Setting the context & Focus on different types of purposes and genres \\
\hline Second & $\begin{array}{l}\text { Modelling, revealing } \\
\text { key features of genre }\end{array}$ & $\begin{array}{l}\text { Global structure of essays/argumentative texts: } \\
\text { - Introduction with a question for discussion } \\
\text { - Body, main arguments } \\
\text { - Conclusion, summing up } \\
\text { Local structure of main paragraphs in essays } \\
\text { - Topic sentence } \\
\text { - Supporting details } \\
\text { - Counter-arguments } \\
\text { - Closing comment }\end{array}$ \\
\hline Third & $\begin{array}{l}\text { Writing practice and } \\
\text { grammar instruction }\end{array}$ & $\begin{array}{l}\text { Exercise with topic: Values and social issues in } \\
\text { the USA, sources given: } \\
\text { - "Brenda's Got a Baby" by Tupac } \\
\text { - Obama's Victory Speech of } 2012 \\
\text { Sources: How to use and refer to sources } \\
\text { Cohesive links: connectors and pronouns } \\
\text { Modality: modal verbs and other modal expres- } \\
\text { sions } \\
\text { Formality level: features of formal and informal } \\
\text { language } \\
\text { Vocabulary work: using dictionaries }\end{array}$ \\
\hline Fourth & $\begin{array}{l}\text { Independent construction } \\
\text { supported by the teacher }\end{array}$ & $\begin{array}{l}\text { Revision of pre-test with } \\
\text { - self-assessment } \\
\text { - peer assessment } \\
\text { - teacher comments and teacher support }\end{array}$ \\
\hline
\end{tabular}




\begin{tabular}{lll}
\hline Fifth & $\begin{array}{l}\text { Comparing to other } \\
\text { genres and contexts }\end{array}$ & $\begin{array}{l}\text { Formal and informal genres } \\
\text { Writing exercise: e-mail to a friend and report to } \\
\text { a police department about Brenda's story (Tu- } \\
\text { pac's lyrics) }\end{array}$ \\
\hline
\end{tabular}

Note: The teaching intervention is based on Feez (1999) and Hyland (2004)

To find out whether the students improved, they were given pre and posttests with open writing-exercises before and after the teaching intervention. The order in which the tests were given was counter-balanced across participants by switching the tests for two of the groups to ensure that possible differences from pre to post-test were not due to the difficulty level of tests. In both tests, the students were to write a text where they discussed American values and social issues in the American society and included relevant sources attached to the exercises. The wording in one test was "Describe some important values in the USA and discuss these in relation to the situation of various people in the modern American society", and the attachments included excerpts from Martin Luther King's speech "I have a dream", and from Coolio's rap lyrics "Gangsta's Paradise". The wording in the second test was "Describe some relevant social issues in the USA and discuss these in relation to important values for the American people", and the appended texts included excerpts from Obama's inauguration speech of 2009 and from Tupac's rap lyrics "Ghetto Gospel". The main differences between the tests were the starting points for discussion and the texts given as appendices.

Furthermore, possible rival explanations were hypothesised and checked before the intervention by mapping various variables that may have influenced the outcome. The variables mapped were gender, first language, grade in written English from lower secondary school and self-confidence level concerning writing factual texts in English. To measure the latter, the students were given a short questionnaire with eight "I can" statements concerning writing factual texts. The statements included the following elements: (1) write an introduction; (2) discuss topics; (3) build paragraphs; (4) write arguments; (5) write a conclusion; (6) organise content; and (7) use connectors to create coherence; and (8) use sources. The students answered on a 7-point Likert scale from $1=$ totally disagree to $7=$ totally agree to these statements. 


\subsection{Samples - teachers and students}

The teachers and the students participating in the study were convenience samples who were recruited using the present author's personal network of friends. Hence, they constitute a non-probability sample (Cohen et al. 2011: 155). Four English teachers and four groups of upper secondary school students participated in the experiment (see Table 2).

Table 2. Distribution of respondents

\begin{tabular}{lccc}
\hline \multirow{2}{*}{ School and group } & \multicolumn{2}{c}{ Teacher } & \multirow{2}{*}{ No. of students } \\
\cline { 2 - 3 } & Work experience & English studies & \\
\hline School 1, group A & Several years & 90 ECTS & 21 \\
School 1, group B & Newly educated & Master's degree & 22 \\
School 2, group C & Several years & Master's degree & 20 \\
School 2, group D & Several years & Master's degree & 20 \\
\hline
\end{tabular}

The participating groups came from two schools. The teachers participating in the experiment had different backgrounds. Three of the teachers had long teaching experience, whereas one teacher was newly educated. Three of the teachers had a master's degree in English, two of them in English linguistics, and one of them in English literature. The fourth teacher had one and a half year of English studies. There were about 20 students who agreed to participate in each group, resulting in a total of 83 participants.

\subsection{Analysis - quantitative and qualitative}

The collected data material consisted mostly of qualitative data in the form of essays written as responses to the pre and post-tests about values and social issues in the American society. This data material was converted into quantitative data through content analysis by giving scores in various categories (Cohen et al. 2011: 564). Each essay was given scores by two of the participating teachers and the present author. There was an overall score of the essays based on evaluation criteria for structure, language and content in ac- 
cordance with the criteria used in examination evaluation guidelines (Norwegian Directorate for Education and Training 2013b). The essays were scored on a scale from 1 (lowest) to 6 (highest) on a total evaluation and on each of the three main categories of structure, language and content. These scores were then used in the statistical analysis of the study's results. In addition, the teachers gave grades on various items included under the three main categories in the evaluation form (see Appendix 1 for all items).

To avoid bias, the author did not know which essays were written as pretests and which were written as post-tests when giving scores. A one-way random intraclass-correlation was computed to check for inter-rater reliability (Thomas et al. 2011:200) of the evaluation of total score on pre and posttest, and also on the main categories of structure, language and content (Table 3). Average measures are reported to indicate the reliability of the mean of several ratings.

Table 3. Intraclass correlation among raters.

\begin{tabular}{lcc}
\hline Evaluation category & Pre-test & Post-test \\
\hline Structure & .66 & .78 \\
Language & .73 & .82 \\
Content & .71 & .80 \\
\hline Total & .76 & .84 \\
\hline
\end{tabular}

Note. Average measures are reported.

On the pre-test, the lowest correlation was .66, and the highest was .76. On the post-test, the lowest correlation was .78 and the highest was .84. The reliability is somewhat low for the pre-test structure, but generally all scores are sufficiently high. From the results here, we see that the raters are more consistent with each other in giving evaluations after the teaching intervention than before.

The gain from pre to post-test was measured, and inferential statistical calculations were performed to assess whether the teaching intervention had a significant effect on the students' writing skills (Howitt and Cramer 2011: 100). Paired t-tests were used to check whether the students had improved significantly, and Cohen's d was calculated to measure the effect of the 
treatment. To see whether the background factors, i.e. gender, first language, grade or self-confidence-level, could explain some of the variance in the results, a multiple regression analysis was performed. The quantitative analysis was complemented by a qualitative analysis examining some essays more closely to see how elements from the teaching intervention that improved are reflected in the essays written as post-tests compared to those written as pretests.

\subsection{Validity}

There are different challenges with making inferences based on an experiment like this one. According to Shadish et al. (2002: 34), validity refers to "the approximate truth of an inference", and two of the main categories of validity they present in their book about experimental designs are internal and external validity. Internal validity refers to whether it was in fact the manipulated variable that caused a possible change, and external validity refers to whether the conclusions can be generalised to other populations. In a teaching intervention such as the one applied in this study, there may be some confounding variables not accounted for. This is a challenge to the internal validity, although the potentially confounding variables of gender, first language, previous written English grade and self-confidence have been controlled for. When it comes to external validity, one challenge is that the participants were not randomly selected. Another problem is the lack of a control-group. As the English subject curriculum and English teaching in upper secondary school seem to comply quite well with genre-pedagogy approaches (Norwegian Directorate for Education and Training 2013a), it would in any case be difficult to include a true control group with a very different teaching strategy in the context of this study.

\section{Results and analysis}

As mentioned earlier, this study investigates what effects applying SFL through genre-pedagogy may have on students' ability to write argumentative texts. The following analysis is divided into two subsections. First, the quantitative analysis shows that the students improved significantly from the pre to the post-test regardless of the background variables that were hypothesised 
to have an influence. Second, there is a qualitative analysis with some examples from student texts. The text examples are included to illustrate some of the improvement revealed in the statistical analysis.

\subsection{A quantitative analysis of the results from pre to post- test}

Improvement is measured by comparing the scores on the pre and post-tests to see if the students improved significantly. To examine this, paired sample analysis was used. The results of this analysis, as well as the results of the scoring of the pre and post-tests, are presented in Table 4.

Table 4. Results of pre and post-tests and gain from pre to post-test.

\begin{tabular}{|c|c|c|c|c|c|c|}
\hline & \multirow{2}{*}{$\frac{\text { Pre-test }}{\mathrm{M}(\mathrm{SD})}$} & \multirow{2}{*}{$\frac{\text { Post-test }}{\mathrm{M}(\mathrm{SD})}$} & \multicolumn{4}{|c|}{ Gain } \\
\hline & & & $\mathrm{M}(\mathrm{SD})$ & $95 \%$ CI. & $\mathrm{T}$ & E.S \\
\hline Structure & $3.13(0.81)$ & $3.74(0.88)$ & $0.61(0.70)^{*}$ & $(0.46-0.76)$ & 7.97 & .72 \\
\hline Language & $3.53(0.78)$ & $3.90(0.81)$ & $0.37(0.58)^{*}$ & $(0.24-0.50)$ & 5.83 & .46 \\
\hline Content & $2.87(0.74)$ & $3.66(0.86)$ & $0.80(0.70)^{*}$ & $(0.64-0.95)$ & 10.41 & .99 \\
\hline Total & $3.10(0.80)$ & $3.75(0.88)$ & $0.65(0.70)^{*}$ & $(0.49-0.80)$ & 8.47 & .77 \\
\hline
\end{tabular}

Note. Paired sample t-tests, $\mathrm{df}=82,{ }^{*} \mathrm{p}<.001$ (two-tailed), effect sizes are calculated as Cohen's d, scale: $1-6$.

As can be seen, the students generally had better results on the post-tests compared to the pre-tests (See Table 4). On the pre-tests, the students' average score was 3.10 with a standard deviation of 0.80 on a scale from 1 as the lowest to 6 as the highest score. They improved to an average score of 3.75 on the post-test with a standard deviation of 0.88 . The mean gain from pre to post-test on the total evaluation was 0.65 . Of the three main categories of structure, language and content, the students scored highest on language on both pre-test and post-test with a mean of $3.53(\mathrm{sd}=0.78)$ and $3.90(\mathrm{sd}=$ $0.81)$ respectively. They improved with an average of $0.37(\mathrm{sd}=0.58)$ on language, with most improvement in the categories of modality and formality level of language (see Appendix 1). With regard to structure, they improved with an average of $0.61(\mathrm{sd}=0.70)$ from an average score of $3.13(\mathrm{sd}=0.81)$ 
on the pre-test to $3.74(\mathrm{sd}=0.88)$ on the post-test. In the category of content, they improved with an average of $0.80(\mathrm{sd}=0.70)$ from an average score of $2.87(\mathrm{sd}=0.74)$ on the pre-test to $3.66(\mathrm{sd}=0.86)$ on the post-test, and they improved most concerning the use of sources (see Appendix 1).

The differences between the pre and post-tests were tested for significance by using paired t-tests as the results were normally distributed. Analysis of the raw scores provided by the raters indicates a statistically significant improvement in the total evaluation from pre to post-test with an effect size of $.77(\mathrm{p}<0.1)$. In all the three main categories, the students also improved significantly $(\mathrm{p}<.01)$ with effect sizes of 0.72 on structure, 0.46 on language, and 0.99 on content. The effect sizes on structure and content are quite large, whereas the effect on language is on a medium level. ${ }^{1}$

In the following, to what extent certain background variables confounded the results is investigated by using multiple regression analysis (see Table 5). The potential confounding variables identified were gender, first language, grade in written English in lower secondary and self-confidence in relation to how well the students thought they could write argumentative texts at the point of the pre-test.

Table 5. Prediction of background variables on gain.

\begin{tabular}{lc}
\hline & $\beta(\mathrm{p})$ \\
\hline Gender & $.10(.44)$ \\
First language & $.13(.29)$ \\
Grade, lower secondary & $.09(.46)$ \\
Self-efficacy, pre-test & $-.32(.02)^{*}$ \\
F(df) & $2.52(4,71)$ \\
R Square(p-value) & $.124(.049)^{*}$ \\
\hline
\end{tabular}

Note. First language is coded $1=$ Norwegian, 2 = others, including English Grade in lower secondary $=$ grade on written English $\beta=$ standardised regression coefficient, $* \mathrm{p}<.05$ (two-tailed)

\footnotetext{
${ }^{1}$ Guidelines developed by Cohen show that 0.80 is to be considered a large effect, 0.50 a medium effect and 0.20 a small effect (Dancey and Reidy 2011: 248).
} 
As displayed, these four variables predicted $12.4 \%$ of the variance in the scores $(\mathrm{R}$ squared $=.124$, see Table 5 ). This showed significance with a $\mathrm{p}$ value of $.049(\mathrm{~F}=2.517)$. Most of the variance in the scores cannot be explained by the selected variables, as only self-confidence shows a significant correlation $(\mathrm{p}=.02)$. This means that the variables gender, first language and grade in lower secondary can be excluded as explanations for the gain between pre and post-tests.

\subsection{A qualitative look at the students' texts}

The statistical analysis of the results showed that the students improved in all the three categories of structure, language and content. In the qualitative analysis, how the students improved is illustrated to complement the quantitative analysis. The text excerpts included here are chosen as they illustrate some of the improvement reported in the quantitative analysis, and are typical examples of how the students improved.

In one student's concluding paragraphs, we see a clear improvement as the style has changed from a somewhat informal style with a strongly expressed opinion to a more formal style with a relatively neutral summary. In the first sentence in the pre-test, this student started the conclusion with a personal expression, saying "My opinion about this is that it is terrible!", ending with an exclamation mark, while in the post-test, the same student started the conclusion with a connector linking the conclusion to the previous text, followed by a summary of what has been discussed: "To sum up we see that America has many different social issues they need to work on." This is one example of how the students improved in writing conclusions and using connectors to create coherence, which are subcategories of "structure" in the quantitative analysis, and using the right formality level, which is a subcategory of "language".

Generally, many students included connectors in their post-tests. As in the previous example, we see here examples of introductory sentences to conclusions: (1) "To sum up, the United States have experienced a change since 1964"; (2) "To sum up, I think that the USA is a great country for opportunities and hope"; and (3) To conclude, the values Martin Luther King wished for are in the American society". The final example here is followed up by a connector that introduces a contradiction: "However, not every individual American get to have an even piece of these values". This illustrates 
that the student used connectors both to structure the answer and to report the main point of the previous discussion. Another student used a connector to indicate that this is the last main point in her argument: "Finally yet importantly, justice is also a value for the Americans". Using a connector that indicates a contradiction is another way of presenting an argument, as illustrated in the following example: "Even though the USA is a country with many values, they still have huge issues like equality differences". All these examples illustrate how students used connectors to structure their arguments after the for-week long teaching intervention.

How to write an introduction was another element of the category of "structure" that showed improvement, and we see an example of this in another student's tests. In the introduction in the pre-test, this student included a general presentation of the topic, though this had a rather vague focus for the following discussion, moving directly to an example:

The topic in this text is about social issues in USA and some values that is important for the American people. USA is a country with big differences between the people. A difference like this is for example racism.

The introduction here generally rephrases what is given in the exercise, and then starts directly on the examples in the introductory paragraph. The introduction in the post-test is more interesting and thorough. Here we also see that the student has used the sources given as he sets a context relating the issue of values to Martin Luther King's speech, leading towards a question for discussion:

In the modern USA, there are many values appreciated by the American people. Their homeland is related to a country with freedom, equality, and justice. Even though the values are appreciated and meant to be good, there are still issues to be solved. Martin Luther King's speech expresses a dream that the American people one day will have equal rights. Does the American society have the values that Martin Luther King hoped they would have? This text will discuss some values in America related to the social issues.

Another aspect the students improved a great deal on was the expression of modality, a subcategory of "language" in the quantitative analysis (see Appendix 1). In one student's conclusion in the pre-test, we see that she expresses some rather clear prejudices about people not used to living with 
black people: "Some people aren't used to living side by side with black colored people, and when they do, they have already made up an opinion about them." This is a rather strong claim about people being racist if they come from a homogenous environment. In the post-test, the same student sums up her ideas and gives a more neutral description of the situation, and her opinion that not everyone has the same opportunities is modified by the word maybe: "I believe that America is a great country, and that it is the land of opportunities, but maybe not for everyone." It is roughly the same idea she presents, namely that life is not easy for everyone in the USA, though the way she presents this idea in the post-test makes a more credible impression.

\section{Discussion}

This study investigates how systemic functional linguistics (SFL) applied through genre-pedagogy may be implemented in the classroom, and what effect this seems to have on students' ability to write argumentative texts. The results showed that the students generally produced better texts after the teaching intervention, and the texts improved particularly in terms of structure and content. The students improved less in the category of language compared to structure and content, but this may be due to the fact that they scored higher in this category to begin with, so there was less room for improvement. In the category of language, they improved most in relation to modality expressions and formality level, grammatical features that were focused on in the intervention. These findings support the conclusions from previous studies on grammar instruction in L2 contexts (Norris and Ortega 2000; Spada and Tomita 2010), that explicit grammar instruction has a positive effect on students' writing skills.

The excerpts from student texts provide examples of the students' improvement, particularly in relation to structure, formality level and modality. However, these are just a few examples illustrating how some of the students actually improved, and cannot be used to generalise the findings of this study. Still, one might argue that the findings of this study are transferable to similar contexts (Lincoln \& Guba, 1985). One might expect that a similar treatment in another school also would lead to improvement.

Even though students are different and have different starting points for learning how to write argumentative texts, this study shows that SFL applied through genre-pedagogy has a positive effect regardless of gender, first lan- 
guage and level. In line with other researchers on genre-based approaches, this study argues that there is a need for explicit instruction and explicit attention to language to support development in writing skills (Byrnes 2012; Humphrey and Macnaught 2015; Hyland 2003; Schleppegrell 2013), and the power of a genre-pedagogical approach like the teaching-learning cycle developed in Australia has not been fully explored in L2 contexts, as pointed out by Martin (2009).

There are certain threats to the reliability and validity of the findings of this study. One should keep in mind that the statistical analysis is based on some subjective evaluations of what the raters might think of as appropriate linguistic choices, such as what is appropriate use of connectors and modal verbs. This makes the rating somewhat unreliable. Still, as the inter-rater reliability is quite high, there seems to be reasonable consensus about what are suitable linguistic choices in argumentative texts. In the multiple regression analysis, various confounding factors were controlled for, like gender, first language, grade and self-confidence level, but other factors than these may have influenced the results as well. For example teacher and student motivation and previous knowledge may also be confounding factors that are a threat to the internal validity of the study.

Even though the statistical analyses in this study show that a genrepedagogy approach to teaching writing may have a significant effect on students' writing skills, the most serious weakness of this study is that it does not investigate whether the students might have had a similar improvement without this type of genre-pedagogy approach - this because there was no control group (Shadish et al. 2002). This is a threat to the external validity of this study that makes it generalising from it somewhat problematical. The students could have improved anyway as they may have matured during a month, and they have worked with the topic being tested before the post-test. They may also do better because at the point of the post-test, it is the second time they write about the same topic. However, as this study is a rather small study, carried out in a natural setting as a field experiment, the goal has not been to make certain predictions and generalisations about students' learning of writing in English, but rather to produce useful knowledge about how SFL may be applied through genre-pedagogy in writing instruction. Hence, this study might yield some interesting insight into a pedagogical approach that explores the possibilities for teaching how to write argumentative texts in L2 contexts. 


\section{Conclusion}

The results of this study support the idea that SFL applied through a genrepedagogy approach to teaching writing may have a positive effect on students' writing skills. Perhaps insights from linguistic theory and research have not been fully exploited in the context of writing instruction. Within linguistics, there is a great deal of knowledge of how language works to create meaning. Whether this knowledge reaches educational contexts and is applied in teaching is, however, unclear. This article advocates that SFL and genre-pedagogy should be implemented in L2 writing instruction contexts, and that this should also be included in the curriculum of the English teacher education in Norway. There is, however, a need to follow up on this study in future research to see if the type of approach demonstrated in this study may offer a fruitful approach across different contexts, also when compared to other approaches.

\section{References}

Andrews, R. 1995. Teaching and learning argument. London: Cassel.

Angelova, M. and A. Riazantseva. 1999. "'If you don't tell me, how can I know?' A Case study of four international students learning to write the US way". Written Communication 16(4). 491-525.

Beard, R. 2000. Developing writing 3-13. London: Hodder Stoughton.

Berge, K.L., L.S. Evensen, F. Hertzberg, and W. Vagle (eds.). 2005. Ungdommers skrivekompetanse Norskeksamen som tekst (Bind 2). Oslo: Universitetsforl.

Bhatia, V.K. 1993. Analysing genre: Language use in professional settings. London: Longman.

Byrnes, H. 2012. "Conceptualizing FL writing development in collegiate settings: A genre-based systemic functional linguistic approach". In: Manchon, R.M. (ed.), L2 writing development: Multiple perspectives. Berlin: de Gruyter Mouton, 191218.

Byrnes, H. 2013. "Positioning writing as meaning-making in writing research: An introduction". Journal of Second Language Writing 22(2). 95-106.

Callaghan, M., P. Knapp and G. Noble. 2012. "Genre in practice". In: Cope, B. and M. Kalantzis (eds.), The powers of literacy. A genre approach to teaching writing. London, Washington: The Falmer Press. 179-202.

Cohen, L., L. Manion and K. Morrison. 2011. Research methods in education. London: Routledge.

Cope, B., and M. Kalantzis. 2012. "Introduction". In: Cope, B. and M. Kalantzis (eds.), The powers of literacy. A genre approach to teaching writing. London Washington: The Falmer Press. 1-21. 
Cope, B., M. Kalantzis, G. Kress, J. Martin and L. Murphy. 2012. "Bibliographical essay: Developing the theory and practice of genre-based literacy". In: Cope, B. and M. Kalantzis (eds.), The powers of literacy. A genre approach to teaching writing. London, Washington: The Falmer Press. 231-247.

Council of Europe. 2003. Common European Framework of Reference for Languages: learning, teaching, assessment.

Dancey, C.P. and J. Reidy. 2011. Statistics without maths for psychology. (5th ed.) Harlow: Prentice Hall.

Education First. 2012. "EF English Proficiency Index (EF EPI)". (3rd ed.) Available at: $<$ http://www.ef.no/epi/>.

European Parliament. 2006. "Recommendation of the European Parliament and of the Council of 18 December 2006 on key competences for lifelong learning". Available at:

$<$ http://eur-lex.europa.eu/legal-content/EN/TXT/?uri=celex\% 3A32006H0962>.

Feez, S. 1999. "Text-based syllabus design". TESOL in Context 9(1). 11-14.

Freedman, A. and P. Medway. 1994. "Locating genre studies: Antecedents and prospects". In: Freedman, A. and P. Medway (eds.), Genre and the New Rhetoric. London: Taylor \& Francis. 1-20.

Freedman, A. and I. Pringle. 1988. "Why students can't write arguments". In: Mercer, N. (ed.), Language and literacy from an educational perspective. (Vol. II: In schools.) Milton Keynes: Open University Press. 233-242.

Gimenez, J. 2008. "Beyond the academic essay: Discipline-specific writing in nursing and midwifery". Journal of English for Academic Purposes 7(3). 151-164.

Graddol, D. 1997. The future of English. London: The British Council.

Graddol, D. 2006. English next (Vol. 62). London: The British Council.

Halliday, M.A.K. and C.M.I.M. Matthiessen. 2014. Halliday's introduction to Functional Grammar. London and New York: Routledge.

Hammond, J. 1987. "An overview of the genre-based approach to the teaching of writing in Australia". Australian Review of Applied Linguistics 10. 163-181.

Horverak, M.O. 2015. "English writing instruction in Norwegian upper secondary schools". Acta Didactica Norge 9(1), Art. 11.

Horverak, M.O. 2016. 'Students' and teachers' perceptions on writing instruction inspired by genre-pedagogy and Systemic Functional Linguistics". Proceedings of CECIL's 5, Olomouc, Czech Republic. 58-73.

Horverak, M.O. Forthcoming. "A survey of students' perceptions of how English writing instruction is carried out in Norwegian upper secondary schools".

Howitt, D. and D. Cramer. 2011. Introduction to statistics in psychology. (5th ed.) Harlow: Pearson.

Humphrey, S. and L. Macnaught. 2015. "Functional Language Instruction and the writing growth of English language learners in the middle years". TESOL Quarterly.

Hyland, K. 2003. "Genre-based pedagogies: A social response to process". Journal of second language writing 12(1). 17-29.

Hyland, K. 2004. Genre and second language writing. The USA: Ann Arbor: The University of Michigan Press. 
Hyland, K. 2007. "Genre pedagogy: Language, literacy and L2 writing instruction”. Journal of second language writing 16(3). 148-164.

Hyon, S. 1996. "Genre in three traditions: Implications for ESL". Tesol Quarterly 30(4). 693-722.

Johns, A.M. 2011. "The future of genre in L2 writing: Fundamental, but contested, instructional decisions". Journal of Second Language Writing 20(1). 56-68.

Joyce, H. 1992. Workplace texts in the language classroom. Sydney: New South Wales Adult Migrant English Service.

Koop, C. and D. Rose. 2008. "Reading to learn in Murdi Paaki: Changing outcomes for indigenous students". Literacy Learning: The Middle Years 16(1). 41-46.

Langdridge, D. and G. Hagger-Johnson. 2013. Introduction to research methods and data analysis in psychology. (3rd ed.) Harlow: Pearson.

Lincoln, Y.S. and E.G. Guba. 1985. Naturalistic inquiry. Beverly Hills, CA: Sage.

Martin, J.R. 1989. Factual writing: Exploring and challenging social reality. Oxford: Oxford University Press.

Martin, J.R. 2009. "Genre and language learning: A social semiotic perspective". Linguistics and Education 20(1). 10-21.

Martin, J.R. 2012. "A contextual theory of language". In: Cope, B. and M. Kalantzis (eds.), The powers of literacy. A genre approach to teaching writing. (2nd ed.) London, Washington: The Falmer Press. 116-136.

Martin, J.R. and D. Rose. 2008. Genre relations: Mapping culture. London: Equinox.

Martin, J.R. and J. Rothery. 2012. "Grammar: Making meaning in writing”. In: Cope, B. and M. Kalantzis (eds.), The powers of literacy. A genre approach to teaching writing. (2nd ed.) London, Washington: The Falmer Press. 137-153.

Norris, J.M. and L. Ortega. 2000. "Effectiveness of L2 instruction: A research synthesis and quantitative meta-analysis". Language learning 50(3). 417-528.

Norwegian Directorate for Education and Training. 2006. Læreplanverket for Kunnskapsløftet midlertidig utgave. Avalable at: $<$ http://www.udir.no/upload/larerplaner/Fastsatte_lareplaner_for_Kunnskapsloef tet/Kunnskapsloftet_midlertidig_utgave_2006_tekstdel.pdf $>$

Norwegian Directorate for Education and Training. 2013a. "English subject curriculum". Available at:

$<$ http://www.udir.no/k106/ENG1-03/Hele/?lplang=eng >

Norwegian Directorate for Education and Training. 2013b. Sensorveiledning i engelsk. Available at: $<$ http://www.udir.no/Upload/Eksamen/Videregaende/H12/ENG1002og1003_En gelsk\%20fellesfag_Sensorveiledning_H12_BM.pdf $>$

Rindal, U. 2012. Meaning in English: L2 attitudes, choices and pronunciation in Norway. (PhD thesis, Oslo University.)

Rindal, U. and C. Piercy. 2013. "Being 'neutral'? English pronunciation among Norwegian learners". World Englishes 32(2). 211-229.

Rose, D. 2009. "Writing as linguistic mastery: The development of genre-based literacy". In: Beard, R. (ed.), The SAGE handbook of writing development. London: SAGE. 151-166. 
Rose, D., M. Rose, S. Farrington and S. Page. 2008. "Scaffolding academic literacy with indigenous health sciences students: An evaluating study". Journal of English for Academic Purposes 7(3). 165-179.

Schleppegrell, M.J. 2013. "The role of metalanguage in supporting academic language development". Language Learning 63(1). 153-170.

Shadish, W.R., T.D. Cook and D.T. Campbell. 2002. Experimental and quasiexperimental designs for generalized causal inference. Boston: Houghton Mifflin.

Silva, T. 1993. "Toward an understanding of the distinct nature of L2 writing: The ESL research and its implications". TESOL Quarterly 27. 657-677.

Spada, N. and Y. Tomita. 2010. "Interactions between type of instruction and type of language feature: A meta-analysis". Language Learning 60(2). 263-308.

Thomas, J.R., J.K. Nelson and S.J. Silverman. 2011. Research methods in physical activity. (6th ed.) Champaign, IL: Human Kinetics.

Walsh, J., J. Hammond, G. Brindley and D. Nunan.1990. Metropolitan East Disadvantaged Schools Program: Factual writing project evaluation. 


\section{Appendix 1: Results, items}

Table 6. Results of evaluations on item level.

\begin{tabular}{|c|c|c|c|c|c|c|}
\hline & \multirow{2}{*}{$\frac{\text { Pre-test }}{\mathrm{M}(\mathrm{SD})}$} & \multirow{2}{*}{$\frac{\text { Post-test }}{\mathrm{M}(\mathrm{SD})}$} & \multicolumn{4}{|c|}{ Gain } \\
\hline & & & $\mathrm{M}(\mathrm{SD})$ & $95 \%$ CI. & $\mathrm{t}$ & E.S \\
\hline $\mathrm{S} 1$ & $3.00(0.75)$ & $3.73(0.87)$ & $0.73(0.77)^{*}$ & $(0.56-0.90)$ & 8.65 & 0.90 \\
\hline $\mathrm{S} 2$ & $3.40(0.94)$ & $4.09(0.91)$ & $0.69(0.79)^{*}$ & $(0.52-0.86)$ & 8.01 & 0.74 \\
\hline $\mathrm{S} 3$ & $3.22(0.90)$ & $3.87(0.93)$ & $0.65(0.77)^{*}$ & $(0.48-0.82)$ & 7.66 & 0.71 \\
\hline S4 & $3.34(0.84)$ & $3.84(0.86)$ & $0.50(0.75)^{*}$ & $(0.33-0.66)$ & 6.02 & 0.59 \\
\hline S5 & $2.74(0.94)$ & $3.65(0.93)$ & $0.90(0.98)^{*}$ & $(0.69-1.12)$ & 8.38 & 0.97 \\
\hline S6 & $3.13(0.86)$ & $3.62(0.87)$ & $0.49(0.68)^{*}$ & $(0.34-0.63)$ & 6.50 & 0.56 \\
\hline S7 & $3.16(0.78)$ & $3.61(0.85)$ & $0.45(0.59)^{*}$ & $(0.32-0.58)$ & 6.92 & 0.55 \\
\hline L1 & $4.49(0.78)$ & $4.82(2.42)$ & $0.33(2.36)$ & $(0.19-0.84)$ & 1.26 & 0.21 \\
\hline L2 & $3.65(0.84)$ & $3.75(0.85)$ & $0.10(0.55)$ & $(0.02-0.22)$ & 1.66 & 0.12 \\
\hline L3 & $3.52(0.88)$ & $3.91(0.88)$ & $0.39(0.57)^{*}$ & $(0.26-0.52)$ & 6.18 & 0.44 \\
\hline L4 & $3.61(0.88)$ & $3.97(0.88)$ & $0.36(0.61)^{*}$ & $(0.23-0.49)$ & 5.37 & 0.41 \\
\hline L5 & $3.47(0.82)$ & $4.02(0.79)$ & $0.55(0.65)^{*}$ & $(0.41-0.69$ & 7.75 & 0.68 \\
\hline L6 & $2.87(0.67)$ & $3.39(0.77)$ & $0.52(0.62)^{*}$ & $(0.39-0.66)$ & 7.64 & 0.72 \\
\hline $\mathrm{C} 1$ & $3.08(0.93)$ & $3.90(0.91)$ & $0.81(0.81)^{*}$ & $(0.64-0.99)$ & 9.18 & 0.89 \\
\hline $\mathrm{C} 2$ & $3.08(0.81)$ & $3.80(0.85)$ & $0.72(0.75)^{*}$ & $(0.55-0.88)$ & 8.71 & 0.87 \\
\hline $\mathrm{C} 3$ & $3.58(0.93)$ & $4.22(0.85)$ & $0.63(0.74)^{*}$ & $(0.47-0.80)$ & 7.84 & 0.72 \\
\hline $\mathrm{C} 4$ & $2.94(0.83)$ & $3.68(0.90)$ & $0.74(0.75)^{*}$ & $(0.57-0.90)$ & 8.94 & 0.85 \\
\hline $\mathrm{C} 5$ & $2.85(0.88)$ & $3.62(0.95)$ & $0.78(0.85)^{*}$ & $(0.59-0.96)$ & 8.28 & 0.84 \\
\hline C6 & $2.30(0.81)$ & $3.40(1.01)$ & $1.10(1.06)^{*}$ & $(0.87-1.33)$ & 9.50 & 1.21 \\
\hline $\mathrm{C} 7$ & $1.68(0.66)$ & $3.00(1.14)$ & $1.32(1.14)^{*}$ & $(1.07-1.57)$ & 10.56 & 1.47 \\
\hline
\end{tabular}

Note: Paired sample t-tests, $\mathrm{df}=82$

$* \mathrm{p}<.001$ (two-tailed)

Effect sizes are calculated as Cohen's d.

Scale: $1-6$.

$\mathrm{S} 1$ = Introduction: How well is the topic and question for discussion/thesis statement presented?

S2 = Paragraph-division: How well are the ideas sorted into paragraphs?

S3 = Topic sentences: How well are the arguments in the paragraphs presented through the topic sentences in the paragraphs? 
S4 = Coherence of arguments: How clear is the writer's opinion throughout the discussion?

S5 = Conclusion: How well does the final paragraph sum up the arguments and give a clear conclusion/answer to the question for discussion?

S6 = Cohesive links: How well is the content logically linked by the use of connectors?

S7 = Cohesive links: How well is the content logically linked by the use of pronouns?

L1 = Spelling: To what extent is the spelling correct?

$\mathrm{L} 2=$ Grammar: To what extent is the grammar correct?

L3 = Sentence complexity: To what degree does the student use complex sentence structure?

L4 = Vocabulary: To what extent does the student show an advanced and varied vocabulary?

L5 = Formality level: To what degree does the student use the appropriate formality level of language?

L6 = Modality: To what extent does the student express degrees of possibility and uncertainty in a good way?

$\mathrm{C} 1$ = Exercise - topic: How well does the text answer the question in the exercise given?

$\mathrm{C} 2$ = Topic: How clear is the topic for discussion in the text?

C3 = Relevance: To what degree are the arguments included relevant to the topic?

$\mathrm{C} 4=$ Thoroughness: How detailed and thorough is the argumentation?

C5 = Discussion: To what degree does the text show different opinions or counterarguments?

C6 = Sources: How well does the student use sources in a sensible and independent way?

$\mathrm{C} 7$ = Literature: How well are the sources referred to in the running text and in a literature list?

Address for correspondence

May Olaug Horverak

Department of Nordic and Media Studies

University of Agder

Gimlemoen 25

4630 Kristiansand S

Norway

may.o.horverak@uia.no 